\title{
Facilitating ESCO market development through value co-creation: role of utility sector intermediaries
}

\author{
Sulafa Badi
}

Received: 8 December 2020 / Accepted: 13 June 2021/Published online: 16 July 2021

(C) The Author(s), under exclusive licence to Springer Nature B.V. 2021

\begin{abstract}
The growth of energy service company (ESCO) markets in the private sector is restricted by a fragmented and highly uncertain market and by customers who are often unknowledgeable and unwilling. This study explores the potential role of utility companies as intermediaries in connecting supply-side ESCOs with potential demand-side customers in a manner that ensures customer satisfaction. The paper adopts a customer-centric, servicedominant logic perspective to examine how a utility company facilitates value co-creation in an in-depth case study of an extensive retrofit programme in the Emirate of Sharjah, United Arab Emirates. The findings underline several value co-creation roles associated with the utility company intermediary, notably relationship-enabling, communication-enabling and knowledge-enabling roles. We conclude with recommendations on how utility companies can facilitate the co-creation of value at the ESCO-customer interface and, hence, support the development of ESCO markets towards decarbonising the built environment.
\end{abstract}

Keywords Energy service companies (ESCOs) . Utility company $\cdot$ Intermediary $\cdot$ Private-sector customer · Value co-creation · Triad · Case study . United Arab Emirates

S. Badi $(\bowtie)$

Faculty of Business \& Law, The British University

in Dubai (BUiD), Dubai, United Arab Emirates

e-mail: Sulafa.badi@buid.ac.ae

\section{Introduction}

The business model of energy service companies (ESCOs) has been recognised as a promising delivery mechanism for energy efficiency (Bertoldi \& BozaKiss, 2017; Bertoldi et al., 2006; Fang et al., 2012; Marino et al., 2010; Vine, 2005). However, despite its potential, the ESCO market is growing at a slow pace, particularly for private-sector customers (Okay, 2020; Recalde, 2021; Yeh et al., 2021). One mechanism that is receiving increasing attention from academia and policymakers for promoting the development of ESCO markets is the role of intermediary organisations (Bleyl et al., 2013; Nolden et al., 2016). Intermediation is defined as 'activities by third parties that help buyers and sellers meet and transact' (Nolden et al., 2016, p.422). Studies of intermediation in the ESCO markets by Bleyl et al. (2013) have found that intermediaries contribute positively by supporting project development, encouraging competition between ESCOs and bridging the cultural chasms between customers and ESCOs. Facilitators were also found to lower the transaction costs of energy efficiency services (Nolden et al., 2016). Despite their potential as an enabling mechanism for energy efficiency, studies of intermediaries' roles in supporting ESCO markets in the private sector are scarce, with relatively little attention given to commercial and industrial customers by researchers. In addition, existing facilitation literature has studied these roles as performed by independent consultants, energy 
efficiency advisories, energy audit companies and legal advisors (Bleyl et al., 2013). No studies have examined the intermediary role of a public-sector utility company. Indeed, while several studies have examined the energy efficiency programmes of utility companies (e.g. Barbose et al., 2013; Eto et al., 1996; Friedrich et al., 2009; Yushchenko \& Patel, 2017), the role of such organisations as intermediaries in ESCO market development has not been studied to date.

Addressing calls for greater understanding of the role of utility-sector intermediaries in promoting ESCO markets to private-sector customers (e.g. Nolden et al., 2016), this study explores how a public-sector utility company can encourage an ESCO's energy service by acting as an intermediary (i.e. 'matchmaker' or 'go-between'; see Murto et al., 2019; de Wilde \& Spaargaren, 2019) between the supply-side ESCOs and the demand-side potential private-sector customers. Conceptually, the energy service is examined from a customer-centric, servicedominant logic (SDL) perspective (Ballantyne \& Varey, 2006; Vargo and Lusch, 2008). This perspective is warranted because a significant proportion of ESCOs operate in (mostly) non-regulated environments, and their market development is ultimately determined by their (potential) customers' decisions to procure or not to procure the ESCO service (Bleyl et al., 2013). Fundamental to this perspective is the concept of value. Value is the basis of all service exchanges, as interacting parties often commence an exchange in anticipation of a positive outcome (Hogan, 2001; Holbrook, 1994; Ulaga \& Eggert, 2006). Value is usually defined as a trade-off between costs (what is given) and benefits (what is received) in a service exchange. The higher the net expected value, the more likely it is that the exchange will take place and be sustained. Value is subjective, relative (i.e. assessed against competitors) and phenomenologically determined by the beneficiary. Therefore, there could be multiple perceptions of value for the same product or service according to the differences among customers' perceptions (Perkins, 1993). In this study, the value of an ESCO's energy service is conceptualised as transcending basic value-in-exchange by including value-in-use. The former concept refers to the value embedded in the energy efficiency products and services delivered by the ESCO and represented by price. In contrast, the latter consists of the phenomenologically determined value that accrues in a specific context through the integration and application of resources to achieve the customer's objectives by the ESCO and other actors (e.g. intermediaries) (Vargo \& Lusch, 2012). Accordingly, value in ESCO energy service settings is not produced by a single firm alone but co-created with the customer and other business actors during the retrofit service experience (Grönroos, 2008). To understand the intermediator role, this paper assumes a 'triadic' perspective that involves the following three actors (we use the acronyms in parentheses to present the actors throughout the paper) (see Fig. 1).

(1) Energy service company (ESCO): a retrofit service provider delivering an Energy Performance Contract (EPC) and associated work.

(2) Utility company (UCO): Sharjah Electricity \& Water Authority (SEWA), a public-sector utility organisation that acts as an intermediary between the ESCO and the customer. The UCO's primary industrial function is to supply electricity, water and gas to the area under study.

(3) End-customer: an industrial or commercial building owner.

A greater understanding of value and the role of the UCO intermediary in value co-creation processes in energy service settings is necessary to successfully support the development of the ESCO market. The triadic perspective contributes significant insight to our understanding of the relational dynamics and dependencies in ESCO project business relationships (Cova \& Salle, 2008; Ford \& Håkansson, 2013; Nätti

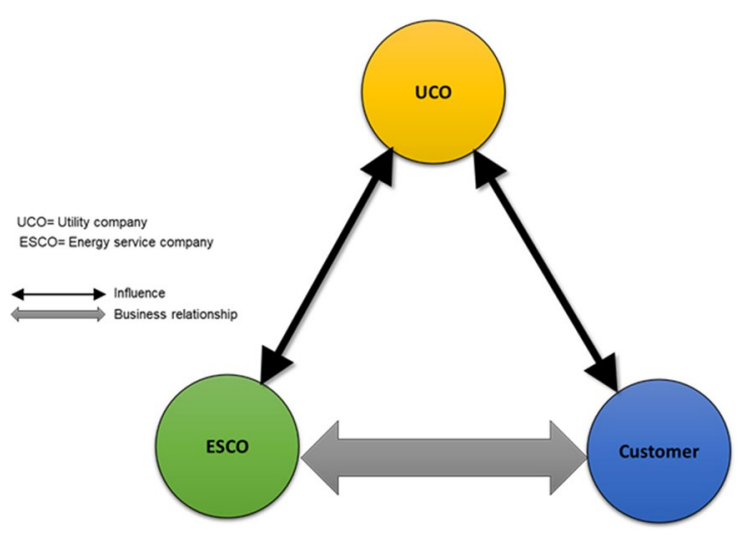

Fig. 1 The triadic relationships under investigation 
et al., 2014; Svensson, 2002). The main questions that underpin our study are.

Question 1: What roles does the UCO intermediary actor play in the triad?

Question 2: What activities does the UCO intermediary actor perform that are associated with these different roles?

An exploratory theory-building approach is adopted to answer the study's questions (Eisenhardt, 1989). A qualitative, in-depth single case study of a significant retrofit programme in the Emirate of Sharjah in the United Arab Emirates (UAE) offered rich insights into and detailed descriptions of the complex interactions and value co-creation activities examined. The approach of the UCO studied was unique in that it sought to promote energy efficiency through incentivisation rather than regulation in the Emirate studied. There is no regulatory requirement to increase energy efficiency in Sharjah, and customers are encouraged, but not forced, to pursue energy efficiency.

By answering the study's questions, the study findings make several noteworthy contributions to knowledge as follows:

- First, the value co-creation activities in intermediated building retrofit services have not been conducted systematically to date, especially in the context of a non-regulated environment.

- Secondly, studies of UCO-led approaches to the development of ESCO markets are absent in the literature. Hence, the current study contributes novel insights by documenting a case study of a UCO-led facilitator role for ESCO market development and demonstrates the contribution to value co-creation in that market. The emergent UCO intermediation model (Fig. 3) provides guidance for intermediary roles and activities as well as support the development of policy recommendations.

- Thirdly, studies on ESCO markets mostly focus on customers in the public sector (e.g. Limaye \& Limaye, 2011; Nolden et al., 2016), while studies of private-sector customers are limited.

- Finally, studies of ESCO markets have been conducted worldwide, including in the UK (e.g.
Nolden et al., 2016), Europe (e.g. Bertoldi \& Boza-Kiss, 2017; Bertoldi et al., 2021; Bleyl et al., 2013; Pätäri et al., 2016), Russia (e.g. GarbuzovaSchlifter \& Madlener, 2013) and Japan (e.g. Iimi, 2013). However, there is a lack of research on the ESCO market in developing countries, especially in the Middle East.

The argument proceeds as follows. The 'Conceptual underpinnings' section presents a literature review on SDL, value co-creation, and value co-creation activities, while the 'Methodology' section provides information on the case study research design and discusses data collection and analysis issues. In the 'Findings' section, the results of the analysis are reported. The 'Discussion' section summarises our findings and discusses emergent insights in relation to existing literature. A final section concludes the paper by outlining conceptual and managerial implications and offering directions for future research.

\section{Conceptual underpinnings}

\section{Energy service companies}

The built environment has a considerable impact on the sustainability of global resources. Buildings consume a substantial amount of energy, amounting to a third of the world's energy consumption, and are responsible for approximately 39\% of global greenhouse gas emissions (United Nations, 2017). One of the most significant current discussions concerns the contribution of retrofitting to the energy efficiency of buildings (Liu et al., 2018; Alam et al., 2019; Moran et al., 2020). Indeed, the retrofit of existing buildings is seen as the 'low hanging fruit' (Kneifel, 2010) in current efforts to reduce global energy consumption. Building energy retrofitting contributes to sustainable development and offers considerable benefits, such as the reduction of the building's life-cycle costs (Jafari \& Valentin, 2017), improvement to the quality of its indoor environment, decrease in the building's carbon emissions, renewal and upgrade of the building's technologies and systems (Bull et al., 2014), and creation of substantial job opportunities (Krarti, 2015). According to the International Energy Agency (2019), to achieve a 30-50\% increase in energy 
efficiency improvement by 2050 , the rate at which the world's existing building stock is being retrofitted will need to be doubled (IEA, 2019b).

Over the last 20 years, ESCOs have been recognised as promising vehicles for energy efficiency through the retrofitting of the existing building stock in both the public and private sectors (Bleyl et al., 2013; Fang et al., 2012; Nolden et al., 2016). With its origin in the USA, the ESCO business model has spread at different rates of development in North America, Europe and Asia. Such companies offer a wide range of energy services, such as energy audit and evaluation, energy management and project design, financing (or finance arrangement) and project implementation (Bertoldi et al. 2006; Fang et al. 2012). As part of the ESCO service, several retrofitting measures can be implemented to improve a building's energy efficiency performance. These may include controlling and monitoring the mechanical systems, upgrading or replacing existing systems with more energy-efficient alternatives and insulating the building envelope. Renewable energy technologies could also be implemented, including solar photovoltaics, biomass and geothermal power systems (Jafari \& Valentin, 2017). A combination of these measures is often selected to develop a retrofit strategy that balances the capital investment necessary to implement the retrofitting measures with the expected benefits from the energy retrofit (Jafari \& Valentin, 2017; Ma et al., 2012). The ESCOs primarily operate under the EPC arrangement. The EPC is a complex and longterm service contract that transfers risks from the client to the ESCO, with the latter responsible for operating and maintaining the newly installed systems for a period ranging from 5 to 30 years (Iimi, 2013; Sorrell, 2007). The ESCO model is unique in that the ESCO typically assumes the project performance risk, with remuneration linked to energy savings achieved (Bertoldi et al. 2006; Garbuzova-Schlifter and Madlener 2013). The EPC is seen to secure the alignment of objectives among contracting parties, as contractors are incentivised to optimise outputs (i.e. energy savings) whilst achieving a cost-effective energy-efficient solution to customers. The ESCOs are espoused to support the attainment of overall national and international sustainable development goals (Taylor et al., 2008; Pätäri et al., 2016; Fang et al. 2012; Garbuzova-Schlifter and Madlener 2013; Nolden et al., 2016; Pombo et al., 2019).
Despite the ESCO business model's potential as a workable approach for the decarbonisation of the built environment, the ESCO market is growing at a slow pace across the world in both the public and private sectors (Okay, 2020; Recalde, 2021; Yeh et al., 2021). As reported by the Energy Efficiency Market Reports, global energy efficiency investment across the buildings, transport and industry sectors grew marginally by only $0.6 \%$ between 2017 and 2018 (IEA, 2019a) and is projected to fall by $9 \%$ in 2020 due to, among other factors, the COVID-19 pandemic crisis (IEA, 2020). The ESCO market is often characterised by high uncertainty, fragmentation, lack of integration and complex calculability (Murto et al., 2019; Owen et al., 2014). Fundamental to the growth of the market are national climate change policies and incentivisation schemes, such as those in some European countries (Bertoldi \& Boza-Kiss, 2017; Bertoldi et al., 2006; Marino et al., 2010; Vine, 2005) and China, the world's largest ESCO market (Zhou et al., 2020; $\mathrm{Zhu}, 2020)$. However, there are significant obstacles damping the growth of the energy service market for private-sector customers. These barriers include misalignment of objectives among tenants and landlords (Nolden et al., 2016), limited customer knowledge and awareness (Pätäri et al., 2016), high transaction costs (Pätäri et al., 2016), competing investment priorities, limited financing options and lack of trust in ESCOs (Limaye \& Limaye, 2011; Vine, 2005; Marino et al., 2010; Larsen et al., 2012; Pätäri et al., 2016). Indeed, the commercial and industrial sectors are lagging behind other sectors (e.g. accounting for only $15 \%$ of the US market; see Nolden et al., 2016). This underlines a need for further scholarly attention to the conditions that may stimulate ESCO market growth for private-sector customers-a gap that we attempt to address in this study.

Service-dominant logic and value co-creation

An increasing number of scholars are adopting SDL as a conceptual lens for understanding service relationships (Barrett et al., 2015). In contrast to the traditional conceptualisation of services (plural) as a unit of output (i.e. an intangible product), SDL defines service (singular) as a process of using one's resources (e.g. knowledge and skills) for the benefit of someone (self or other). Service provision within this context is conceptualised as a process 
whereby multiple social and economic actors engage in resource integration for mutual value co-creation (Wieland et al., 2012; Vargo and Lusch, 2008; Vargo \& Lusch, 2008). Essentially, the initiation of interactions among service actors is brought about by a value proposition being offered by a particular network actor. In Vargo et al.'s (2015) view, 'value propositions are always the co-created outcomes of systemic human action' (p. 7). This value proposition is subsequently either accepted or rejected by another network actor. ${ }^{1}$ If a value proposition is accepted, a service exchange will occur, and, ultimately, these value processes will result in value being co-created and, at times, being co-destroyed (Laud et al., 2019).

Prior research on conceptualising value co-creation activities have mostly focussed on the dyadic relationships between customers and service providers (Ballantyne \& Varey, 2006; Lambert \& Enz, 2012). Assuming a dyadic view of business-to-business relationships, Lambert and Enz (2012) contended that value co-creation occurs through interactions in three key iterative and interconnected stages: 1) joint crafting of value propositions, 2) value actualisation and 3) value determination. Ballantyne and Varey (2006), on the other hand, emphasised three exchange enablers that facilitate the co-creation of value: relating, communicating and knowing. Relating is concerned with the relationship development that forms the supporting structures for actors to create and apply knowledge resources; communicating refers to actors interacting to develop these relationships; and knowing is concerned with the mutual learning and knowledge renewal required to improve the value delivered to the customer.

Few studies have adopted a triadic approach towards value co-creation. In a triad, one actor could be playing an intermediary role between the other two actors (Ritter, 2000), building relationships through information gatekeeping, bridging, the promotion of service and the negotiation of contracts ( $\mathrm{Li} \&$ Choi, 2009). Among the handful of studies that take a triadic approach to service relationships is Nätti et al.'s (2014) work on the role of the intermediary in the triadic property maintenance service business,

\footnotetext{
1 This account, however, is a simplistic dyadic view, given that value propositions could be presented by one actor to many, many to one or many to many.
}

which involves a property manager, a housing association and a property service company. Nätti et al. (2014) identified four key value co-creation activities, including elucidating (i.e. matching value propositions), accelerating service processes, word-of-mouth marketing and conciliating in service recovery. While dyadic approaches are abundant in the marketing research domain (e.g. Barnes et al., 2007; Leek \& Mason, 2009; Tanskanen \& Aminoff, 2015; AarikkaStenroos \& Jaakkola, 2012; Sampson \& Spring, 2012), few studies have taken a triadic approach to explore value co-creation in business service settings (e.g. Chowdhury et al., 2016; Havila et al., 2004; Li \& Choi, 2009; Nätti et al., 2014; Vedel, 2010). Our study aims to contribute to the paucity of triadic perspectives in value co-creation by investigating the ESCO-UCO-Customer triad. This approach not only allows a rich insight into the dynamics of value cocreation in building energy service but also identifies the role and activities of each actor involved and elucidates the relational structure that underpins value co-creation.

\section{Methodology}

\section{Contextual background}

In the UAE, buildings' energy consumption amounts to a staggering $90 \%$ of the country's total electricity consumption. A significant proportion of this energy is used in buildings' air conditioning due to the country's arid climate (Dubey \& Krarti, 2017). The UAE's energy consumption has nearly doubled over the last decade. The retrofit of the UAE's existing building stock could reduce its total energy consumption by almost 50\% (Dubey \& Krarti, 2017). In an energy simulation study by Dubey and Krarti (2017), it was estimated that the deployment of a large-scale deep energy retrofit programme would achieve savings of 47,200 GWh/year in electricity consumption, together with an 8,802 MW decrease in peak power demand. A 28.5 million tonnes/year reduction in carbon emission could also be achieved (Dubey \& Krarti, 2017). The study also underlined the costeffectiveness of retrofitting buildings, with payback periods of only 2.3 years for a deep retrofit of the entire UAE building stock (Dubey \& Krarti, 2017). Given the fertile environment, there is considerable 
potential for ESCOs to grow as a delivery mechanism for energy efficiency. However, a study by the Clean Energy Business Council (2019) identified customers' unwillingness as the biggest stumbling block for the growth of the UAE's ESCO market, coupled with contractual complexity and the lack of project funding. The report also established that the market is relatively young, with approximately 25 ESCOs operating in the UAE; $57 \%$ of these are less than five years old (Clean Energy Business Council, 2019). Hence, to stimulate the energy service market, there is an urgent need for policymakers to foster interactions between potential customers of energy retrofit services and service providers and to support greater collaboration between public and private actors in the energy sector (Murto et al., 2019).

The case study approach

This study adopted a constructivist ontology, which views reality as constructed through the actors' actions and perceptions of the phenomenon under investigation (Zikmund, 2000). Value co-creation in energy service settings is a context-specific social process. Therefore, it is highly influenced by the perceptions of actors in a project and the unique characteristics of the retrofit service. This study was also epistemologically interpretive in that it considered value co-creation to have multiple subjective meanings for the actors involved. The researchers engaged in 'sensemaking', by interpreting the meanings behind the study participants' accounts of their energy service experiences and their views of the triadic relationships and their dynamics (Bryman \& Burgess, 1994). An exploratory, qualitative case study approach was considered the best suited for this research, because the issues involved in value co-creation are undefined, complex, interconnected and difficult to measure quantitatively (Eisenhardt $\&$ Graebner, 2007). The case study research strategy enabled the examination of the real-life experience of building energy service and enabled a full description of the concepts of value and value cocreation as observed in the studied environment (Flyvbjerg, 2006; Yin, 2003).

In this research, case selection was purposive, and a single unique case of a significant retrofit programme in the Emirate of Sharjah, UAE, was chosen. The retrofit programme was a reasonably bounded, isolated and temporally defined entity that could be considered as a case for analysis (Yin, 2003). In 2017, SEWA introduced an Energy Efficiency Programme in line with a governmental aspiration for Sharjah to become the UAE's 'City of Conservation' and a commitment to a $30 \%$ reduction in energy and water consumption by 2030. As part of the Energy Efficiency Programme, the SEWA launched the retrofit programme in 2018 , with the target market being the highest energy consumers in the city, 'The Top 100'. This category includes industrial (41\%), government (33\%) and commercial (26\%) buildings. The SEWA started the ESCO registration and qualification process at the end of 2017, with approved ESCOs capable of completing projects across Sharjah. Following registration, the SEWA assumes the role of intermediary, facilitating the ESCO's relationship with customers through a series of enabling activities. The SEWA exclusively plays this intermediary role, and no other industry associations perform a similar function within Sharjah. At the time of data collection (June-October 2020), 10 ESCOs had joined the programme, and 27 retrofit projects were progressing in parallel across Sharjah, including industrial, commercial and governmental buildings. A variety of energy efficiency technologies were implemented through ESCO projects, including the optimisation of heating, ventilation, air conditioning (HVAC) system-chiller plants, fresh-air handling unit (FAHU/AHU) controls, hot water system replacements and lighting replacements. Figure 2 provides further details concerning the ESCO project development process facilitated by the UCO.

\section{Data collection}

The study's focus was on the interactions between three types of organisation involved in the retrofit programme to deliver a long-term EPC contract, including the ESCO, the customer and the UCO. Figure 1 illustrates the triadic relationships studied. Data collection involved 15 semi-structured interviews with representatives from the UCO (three interviewees), the ESCOs (six interviewees from four different ESCOs) and the customers (three interviews with an industrial customer and three with a commercial customer). The criteria for selecting the respondents were as follows: 1) the respondent had a direct and active role in the energy retrofit project; and 2) the 


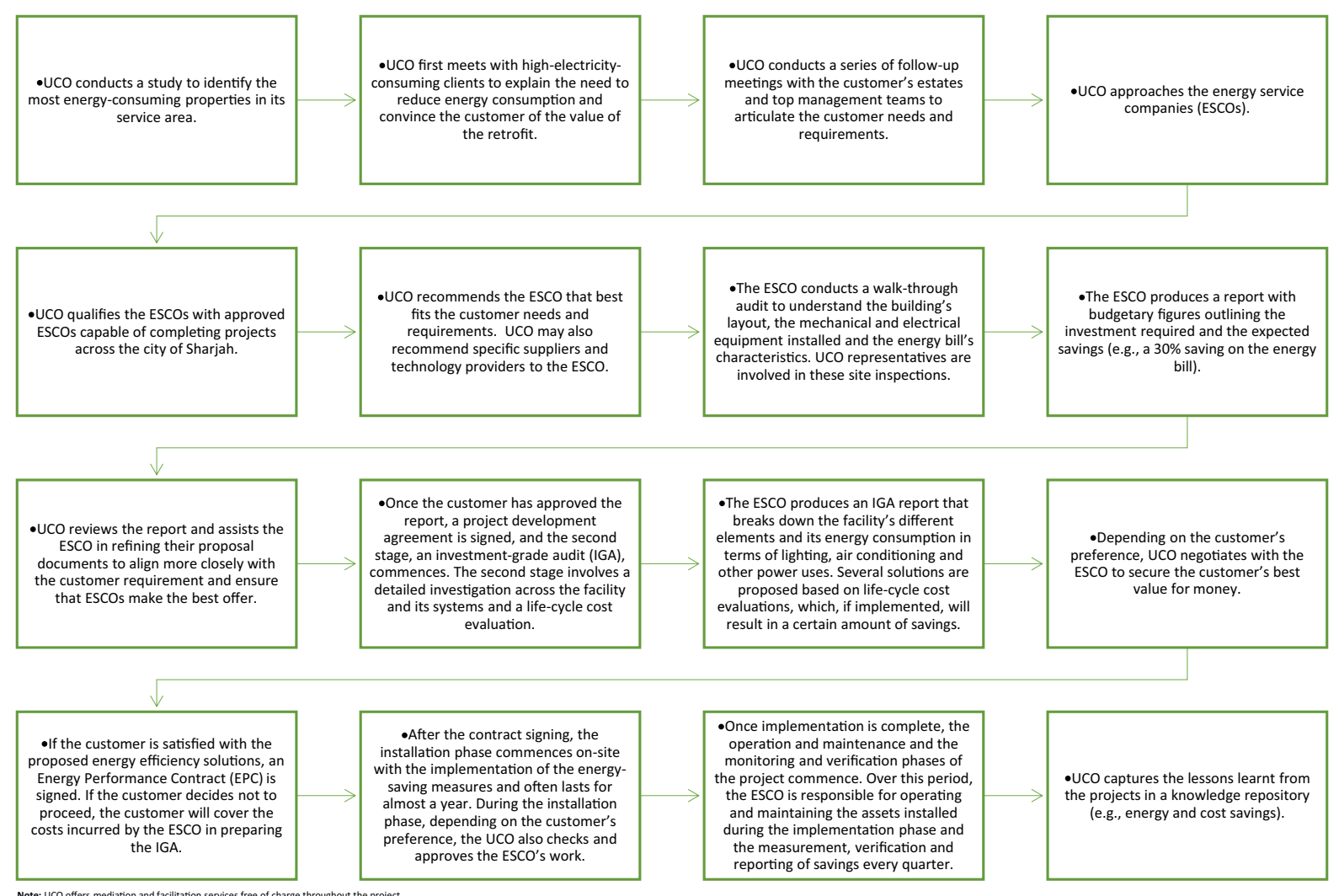

Fig. 2 The utility company (UCO)-mediated project development process

respondent was identified and endorsed by at least one other project participant as playing an essential role in the project development process. Table 1 lists the study's participants.

A standard interview protocol was developed to support the reliability of the study's findings (Yin, 2003). The interview questions delved into the interviewees' company background, involvement in the retrofit programme and relationship with the other project actors, viewed in the context of the triadic relationship dynamics. Appendix Table 5 provides further details concerning the interview protocol. Data collection was conducted over five months between June 2020 and October 2020. Eliciting participants for the study continued throughout this period until no new insights emerged as interview evidence accumulated, signalling theoretical saturation (Beverland \& Lindgreen, 2010; Eisenhardt \& Graebner, 2007). Actual information redundancy took place before the 14th interview. Hence, it was decided that data collection would conclude by the
Table 1 Study participants

\begin{tabular}{llll}
\hline No & $\begin{array}{l}\text { Years of } \\
\text { experience }\end{array}$ & Company & Position \\
\hline 1 & 21 & ESCO1 & Business Manager \\
2 & 16 & ESCO1 & Project Manager \\
3 & 17 & ESCO2 & Sales \& Operations Manager \\
4 & 12 & ESCO3 & General Manager \\
5 & 6 & ESCO3 & Marketing Manager \\
6 & 13 & ESCO4 & General Manager \\
7 & 4 & UCO & Project Manager \\
8 & 3 & UCO & Engineer \\
9 & 4 & UCO & Chief Efficienology Officer \\
10 & 7 & CUS1 & General Manager (industrial) \\
11 & 4 & CUS1 & Maintenance Engineer (industrial) \\
12 & 11 & CUS1 & Operations Manager (industrial) \\
13 & 16 & CUS2 & Business Owner (commercial) \\
14 & 5 & CUS2 & Business Owner (commercial \\
15 & 23 & CUS2 & Operations Manager (commercial) \\
\hline
\end{tabular}


15th interview. While the UCO-ESCO-Customer triad was the study's focus, participants were also prompted to reflect on how the focal actors interacted and were influenced by other actors, allowing insights into the wider service network. Interviews took between 60 and 90 min to conduct. All interviews were conducted in the English language, recorded and later transcribed verbatim. The data collection also included reviewing case-related documentation such as walk-through audit (WTA) and investment-grade audit (IGA) reports, the UCO's retrofit strategy and sustainability initiatives reports. This use of multiple sources aided in illustrating the diversity and richness of the social environment observed (Neumann, 2000).

At the time of data collection, most of the ESCO projects were at the implementation or early monitoring and evaluation stage. Hence, quantifiable data on retrofit programme results and outcomes were not available to be reported in this paper. Moreover, the UCO was not involved across all retrofit projects in Sharjah, as several ESCO projects were initiated by the customers themselves by directly approaching the qualified ESCO or by the ESCO's contacting the customers to present their services following qualification and registration. These projects lacking UCO involvement were not included in the study.

\section{Data analysis}

The thematic data analysis of the textual interview data began early from the first interviews and continued throughout the data-collection period, facilitating overlapping data collection and analysis. This approach enabled timely analyses and allowed minor adjustments to be made to the data-collection instrument. It also allowed the researchers the time to be more reflective and immersed in the data, enabling them to spot patterns in the interviewees' responses as the interviews unfolded. The analysis was conducted in several steps, including exploration, coding, theme development, reflection and synthesis (Glaser \& Strauss, 1967; Leech \& Onwuegbuzie, 2011). In the thematic analysis, a set of pre-defined codes was used, while the researchers kept an open mind about identifying emergent codes as they read the transcripts and allowed the data 'to speak'. Iterative tabulation of evidence was performed for each emergent construct as the evidence converged from multiple interviewees into concrete findings. To validate the findings, the case report was sent to three interview participants who were asked to review these results and offer feedback. A detailed account of the findings is presented in the following section.

\section{Findings}

In this section, the findings are summarised and illustrated with quotes from the interviews. By reflecting upon Ballantyne and Varey's (2006) exchange enablers model, our findings identified three value cocreation roles associated with the UCO intermediary actor in the triadic energy service setting: relationship-, communication- and knowledge-enabling roles. These will be presented in the 'Relationship-enabling roles and activities', 'Communication-enabling roles and activities', and 'Knowledge-enabling roles and activities' sections, respectively.

Relationship-enabling roles and activities

In service interactions, 'relating' is concerned with relationship development that forms the supporting structures for actors in creating and applying knowledge resources (Ballantyne \& Varey, 2006). Table 2 lists the observed UCO intermediary relationshipenabling roles and activities. The findings underline two relationship-enabling roles associated with the UCO intermediator actor: orchestrator of the value network and co-developer of trust, as discussed below.

\section{Utility company intermediary as the orchestrator of the value network}

The SEWA, referred to as the 'UCO' in the remainder of this section, has decided to abandon the 'stick' in favour of the 'carrot' in its effort to stimulate energy efficiency through incentivisation rather than regulation in its vicinity. There is no regulatory requirement to increase energy efficiency in Sharjah, and customers are encouraged, but not forced, to pursue energy efficiency, as explained by the UCO's Chief Efficienology Officer:

It is very easy to add a regulation in Sharjah, but it is not our methodology... we don't have any regulation to force customers to participate in 
Table 2 Utility company (UCO) intermediary relationship-enabling roles and activities

\begin{tabular}{ll}
\hline $\begin{array}{l}\text { UCO intermediary relationship-enabling } \\
\text { roles }\end{array}$ & Activities observed \\
\hline Orchestrator of the value network & - Market scoping and segmentation by identifying \\
& high energy-consuming customers \\
& - Convincing customers of retrofit value \\
& - Articulating customer requirement through free \\
& energy audits and broad financial assessments \\
& - Qualifying the energy service companies (ESCOs) \\
& - Marketing ESCOs through direct project referrals \\
& and endorsements \\
& - Recommending suppliers and technology providers \\
& - Building customer's goodwill and competence trust \\
& - Brokering trust across the ESCO-customer interface
\end{tabular}

the programme, but we are trying to show them what SEWA can do and offer and how they will benefit if they join. (Chief Efficienology Officer, UCO; Construction Week, 2018)

To increase the demand for the energy retrofit service, the UCO initiated the programme by conducting a comprehensive study to identify the most energyconsuming properties on their records. This evaluation was mainly performed as a demand management strategy (Slack \& Brandon-Jones, 2019) to ensure the UCO's capacity to meet energy demands in their vicinity. Following this process, the 'Top 100' energy consumers in the Sharjah were identified. These customers were considered the target market for the UCO's retrofit initiative to support Sharjah's goal of achieving $30 \%$ energy savings by 2030 . Following identification, these highly consuming customers are approached by UCO representatives, and meetings are organised to discuss the customer's energy consumption and to explain the need to reduce energy consumption by implementing energy efficiency measures. The UCO is able to perform these valueadding activities based on the detailed information in their records regarding the energy consumption of the customers that they serve. In these initial meetings, the UCO attempts to convince the customer of the 'value' of the retrofit by demonstrating the severity of their situation and the magnitude of the deviation of their energy bill from the average level of consumption in Sharjah, as explained below:

[W]e came to inform them that they are one of the highest consumers in Sharjah, and they did not know that. That news was shocking to them! (Project Manager, UCO)
During these initial meetings, the UCO team spends a significant amount of time understanding and articulating the customer's requirements and the drivers behind their motivation to reduce their energy consumption. In what was described in our study by one UCO representative as 'pain points', customers' concerns often relate to their aspirations for cost savings in terms of the reduction of the energy bill and maintenance costs. These early enabling activities also include a free energy audit and broad financial assessments of potential economic savings and the net present value of future savings. Customers interviewed for this study cited their lack of knowledge of energy efficiency and its remoteness from their primary business activities as obstacles that were partly surmounted by these initial engagements. In addition, the involvement of the customer's top management team was considered to be a success factor at these early project stages as it enabled greater understanding of the customer's business and their priorities, the project's goals and the financial and skill resources available. The outcome of these engagement meetings is an initial estimation of possible solutions to increase the building's energy efficiency through retrofitting measures. Clear definitions are also developed in terms of the potential benefits of the adoption of the ESCO business model as well as the projectspecific goals, contextual requirements and elements of the energy service package. These UCO-enabled project development activities effectively create a 'demand pull' (Hannon et al., 2015) for energy service projects with which ESCOs can subsequently engage.

On the supply side of the retrofit service, the UCO is also the first to approach the ESCOs and 
introduce the retrofit programme. The $\mathrm{UCO}$ is the body that qualifies the interested ESCOs for the retrofit projects within Sharjah. As part of the qualification, field certification is performed through visits to existing ESCO projects across the UAE and through the observation of ongoing audits. The UCO also assesses ESCO staff capabilities in terms of qualifications, technical skills and experience. Following qualification, the UCO subsequently selects and recommends the ESCO that best fits specific customer needs and requirements. Being distinctly different from competitive ESCO procurement practices in other parts of the world (e.g. Bleyl et al., 2013; Iimi, 2013; Nolden et al., 2016), there are no tendering or bidding processes for selecting the ESCO in Sharjah. The selection and award criteria highly favour an ESCO's flexibility and experience of the building type. The flexibility of the ESCO was an essential criterion as the retrofitting activities significantly affects the day-to-day operational processes of commercial and industrial customers and ultimately their revenue. Hence, it is important to carefully select an ESCO with experience in the sector and the flexibility to cater for unforeseen operational eventualities. The UCO is, consequently, not a neutral observer; instead, the UCO assumes considerable 'reward' power (French \& Raven, 1959) as the decision-maker with regard to determining which specific ESCO is introduced to a particular customer.

In addition, the UCO not only introduces the ESCO to the customer but also recommends specific suppliers and technology providers to the ESCO. These endorsements are based on market knowledge gained through visits to these suppliers' facilities, mostly in Europe, and by assessing their technologies. In recommending suppliers to the ESCO, the role of the UCO can, accordingly, be described as the designer of the service ecosystem (Frow et al., 2014; Vargo et al., 2015) or the 'orchestrator' of the value network (Natti et al., 2014) for the energy retrofit service within Sharjah. In our study, all ESCO interviewees emphasised the importance of the UCO in stimulating recent market growth, as indicated by this quote from an ESCO business manager:

They did put in context supply and demand. Sometimes they call us, and at other times they call our competition. Obviously, they try to bring the market and facilitate the development of this, not only for one company but for many. (Business Manager, ESCO)

As observed from the findings, the UCO performs a distinct marketing function on behalf of the ESCO by helping the ESCO to win new projects. In return, the UCO secures the ESCO's cooperative behaviour. Subsequently, ESCOs are encouraged to accommodate the UCO's requirements to sustain this relationship and be awarded future projects:

[...] Whenever you call the ESCO saying that

'...you know, ESCO we have a new business for you', they will immediately run to you and say, 'OK, WOW! ...they care about us, about getting us business, about showing the best out of the best that we can create as an ESCO', so they are going to contribute into your requirement, they are going to do what you ask them to do, they are going to take into consideration the comments that you raise. (Engineer, UCO)

Therefore, in a well-developed UCO-ESCO relationship, the ESCO marketing effort can benefit through direct project referrals and endorsements made to potential customers by the UCO.

\section{Utility company intermediary as co-developer of trust}

Trust is an essential dimension of relationship quality and value co-creation (Dorsch et al., 1998; Hewett et al., 2002; Hibbard et al., 2001; Ulaga \& Eggert, 2006). Indeed, trust and value propositions are often considered to be formulated jointly in business-tobusiness relationships (Morgan \& Hunt, 1994; Nätti et al., 2014; Wilson, 1995). While there are several definitions of trust in the literature, it is primarily conceptualised as one exchange party's confidence in the integrity, benevolence and credibility of the other party (Moorman, 1993; Morgan \& Hunt, 1994, Doney \& Cannon, 1997; Svensson, 2004). Trustworthiness is a cornerstone of successful exchange relationships and is manifested in keeping one's promises and considering the welfare, best interest and success of the other party (Ulaga \& Eggert, 2006). In SDL, trust is viewed as the foundation of effective dialogue because, without trustworthiness among the exchange partners, the dialogue ceases to continue (Ballantyne and Varey, 2006). 
As part of its relationship-enabling activities, the role of the UCO intermediary as co-developer of trust was critical in the service triad. The ESCOs involved in this study agreed that the development of trust with the customer was problematic due to the customers' limited knowledge of project development and EPC mechanisms. Moreover, customers were often sceptical about potential energy savings and viewed ESCOs as 'outsiders coming to tell them how to run their building'. As one ESCO general manager explained:

[...] You have to recognise that when we step into a facility, we are an outsider. Yeah. And you have a technical team who have been working there for the last maybe five years. And then you come with a magic wand and tell the customer, 'you know you can save 20\%' ....immediately, they will feel a little bit defensive because they feel, why they haven't come up with these solutions before? (General Manager, ESCO)

In this context, where the development of ESCO-customer trust was challenging, the role of the UCO was pivotal as the co-developer of trust in the triad. In particular, the established relationship of trust between the UCO and the ESCO influenced the perceived trust of the customer and enabled ESCO-customer trust to develop. This dynamic was explained by one ESCO business manager:

[...] This is why it was so important to have SEWA on that road. Yeah. Because they told them, 'Look, these guys have been in this business for many years. We have tried their services. They're very good; I recommend them.' So obviously, the level of trust was much higher than in other companies where we just didn't have anybody to support us. (Business Manager, ESCO)

Indeed, the building of UCO-customer trust was intentional on the part of the UCO team and was an essential element in the service design. From the findings, it was observed that the UCO team pursued several trust-building strategies to cultivate two specific dimensions of trust: 'goodwill' trust (Jiang et al., 2013; Lewis \& Weigert, 1985) and 'competence' trust (Das \& Teng, 2001; Nooteboom, 1996). First, the UCO ensured the customer's trust in its goodwill by expressing concern about its energy consumption. Although the customer was paying the UCO for the electricity, the customers involved in this study appreciated that UCO was interested in reducing their energy cost through retrofitting measures. Moreover, the customer's goodwill trust was developed by the UCO by offering its consultancy and project facilitation services free of charge. In comparison, earlier research by Bleyl et al. (2013) found that project facilitation cost is an obstacle for European energy service projects and amounts to an average of $3 \%$ of the total investment cost. Hence, the offering of the service free of charge significantly reduces transaction costs to the UCO's customers. This strategy was intended to develop a trusting relationship with the customer, as explained by one UCO team member:

We do everything free of charge for the customer because, in the end, we want the customer to get the benefit and to save that energy and to trust us that we want to share that knowledge rather than taking a commission out of the service. (Engineer, UCO)

The second dimension of trust is competence trust, which emerges through a rational evaluation of a trading partner's capabilities to meet the requirements of the exchange (Das \& Teng, 2001; Nooteboom, 1996). Trust in the UCO's competence was particularly important, given that the majority of the customers lacked the knowledge and expertise needed to make an informed decision and were hesitant about engaging in a long-term contractual relationship with the ESCOs. A customer representative illustrated this point:

We say, 'OK, SEWA, you can discuss, you can negotiate on our behalf because we trust that the price you recommend will be fair... you know the market, you know how much it costs'. (General Manager, CUS)

Hence, the co-development of trust among the triadic actors was an explicit strategy pursued by the UCO. This strategy supported the co-creation of value with the customer throughout the customer service experience. In particular, the customer's trust in the UCO's integrity and judgement was instrumental in encouraging the customer to sign the contract, and it enabled the exchange to take place between the ESCO and the customer, as explained by one ESCO business manager: 
You know, when the CEO finally joined that conversation, she looked at [name of UCO Chief Efficienology Officer] and said upfront, 'If you sign it, I will sign it.' (Business Manager, ESCO)

Communication-enabling roles and activities

Communicating involves actors interacting to develop relationships for value co-creation (Ballantyne \& Varey, 2006). Table 3 lists the observed UCO intermediary communication-enabling roles and activities. The findings identified two particular communication-enabling roles performed by the UCO intermediary: as the facilitator of the 'trialogue' and as the 'joint crafter' of the value proposition.

\section{Utility company intermediary as a facilitator of the trialogue}

According to the findings, the value proposition (i.e. details of the EPC) was 'jointly crafted' (Lambert \& Enz, 2012) or 'co-produced' (Natti et al. 2014) by the three triad actors following two detailed energy audits (i.e. WTAs and IGAs) and extended negotiations between them. The objective of these negotiation trialogues (Natti et al. 2014) was to establish a value proposition in the form of an EPC with technical and financial structuring most satisfactory to both the customer and the ESCO. The value proposition was framed as energy bill savings by installing cost-effective energy efficiency technologies. This value proposition was supported by life-cycle cost evaluations and payback periods, among other economic assessments. The two energy audits and subsequent discussions also played an overarching role in the value cocreation processes, as they enabled all three actors to refine their activities. These 'diagnosing' audits and discussions allowed the ESCO to understand the customer needs and requirements and the UCO's preferences. They also provided the customer with the opportunity to diagnose their own building's technology/processes and acquire in-depth energy efficiency knowledge. During these early stages, the UCO choreographed these meetings and took an active role in guiding the customer through the process. In the current study, this role was critical in bridging the communication gap between the customer and the ESCO due to their diverging organisational cultures, concerns and expectations. The significance of the UCO in this trialogue was emphasised by one ESCO business manager when he provided an anecdote:

[...] Again, this is very important. First of all, to bridge the gap in terms of communication, understanding the way we do business. It's about guiding them [the client] through the process; it is like taking your car to the workshop, and you don't know anything about where you are going... If you go to the workshop and you have someone who has been in the business, you know, of repairing cars. And then he can tell you, 'Look, take your car to this workshop and don't go to that one because that one is rubbish'. That's obviously something that you consider of value. (Business Manager, ESCO)

As can be seen from this quote, the UCO's intermediary role was crucial, given customers' limited knowledge. Customers are also unaware of what could be realised through the retrofitting and of what to expect from the ESCO service offering. During the process, the UCO takes an active role in ensuring that the customer who is not an expert in energy retrofits is suitably informed about the market and has

Table 3 Utility company (UCO) intermediary communication-enabling roles and activities

\begin{tabular}{ll}
\hline UCO intermediary communication-enabling roles & Activities observed \\
\hline Facilitator of the trialogue & - Choreographing energy service company (ESCO)-customer communication \\
& - Managing customer knowledge and expectations \\
Joint crafter of the value proposition & - Reviewing and assessing the ESCO's offer (depending on customer prefer- \\
& ence) \\
& - Negotiating with the ESCO to secure best value for money (depending on \\
& customer preference) \\
- Managing project progress, checking and approving ESCOs work (depend- & ing on customer preference)
\end{tabular}


clear expectations of the service offering. If such support were not available to the customer, they might be reluctant to engage with the service. The greater their understanding of the market and the retrofit service offering, the more likely the end-customer is to engage in the exchange.

\section{Utility company intermediary as 'joint crafter' of the value proposition}

In the early negotiation stages, the UCO supports the ESCOs in making the best offer to the customer. In what was described by the UCO's representatives as a 'detailed relationship', the UCO is involved in all aspects of the service encounter regarding site inspection, drafting the audit reports and presenting the audit report to the customer. They also provide advice to the chosen ESCO to improve their WTA and IGA report details. The UCO's representatives explained this approach to 'sustain' their relationship with the ESCOs and ensure customer satisfaction, with one UCO team member elaborating as follows:

We would say, 'Why don't you improve your report by putting in this and that, this will satisfy the customer, why don't you do that' [...] for us, because we want to sustain our relationship, to make sure that the ESCOs that work with us are giving the best and satisfy our customers. (Engineer, UCO)

As there are no tendering or competitive bidding processes in the case setting to appoint ESCOs, the UCO assumes a considerable role as the 'joint crafter' of the value proposition. This role, however, differs based on the level of engagement of the customer. An active customer may negotiate directly with the ESCO, whereas a more passive customer may seek a more prominent role for the UCO in the negotiation stage. In the latter scenario, the UCO negotiates with the ESCO to secure the best price for the customer and fine-tunes the technical and financial structuring of the EPC contract. Through a series of negotiations, the ESCO's offer is reviewed by the UCO's financial department to ensure that the life-cycle cost assessment is fair in terms of the technical solution, the implementation timeline, the maintenance schedule and overall project design. The outcome of these reviews is an EPC contract that offers the best value for money for the specific customer requirement. The UCO's Project Manager explained this point further:

We negotiate. We make sure that when we are going to share that offer with the customer, it's the best out of the best, so we don't bring that extra headache to the customer into understanding where each dirham is going! (Project Manager, UCO)

Following the signing of the EPC contract ${ }^{2}$ and during project implementation, depending on the customer preference, the UCO's team may assume project management roles, such as checking and approving the work completed by the ESCOs. This dynamic has to be considered when attempting to elucidate the value co-creation activities in the retrofit business setting. In particular, in the case of a customer with low expertise in retrofitting, the UCO may adopt a crucial and prominent mediating role in enhancing the value co-creation in the triad alongside the ESCO.

A well-functioning triad also requires greater transparency than usual from all the parties involved. In the extant literature, trust and transparency are considered to be interrelated (Hultman \& Axelsson, 2007) and contribute to customer-perceived value and satisfaction (Eggert \& Helm, 2003). In the present case study, the triad parties' ability to 'see through' and share information that is usually not shared between business partners supported developing a value proposition that was the best fit for the customer. One UCO representative noted that, in a hotel retrofit project, the owner's transparency regarding their finances and the budget allocation was influential in crafting a value proposition (i.e. a technical solution) that best fit the customer requirement. The following quote from a UCO team member illustrates this observation:

The manager was very much transparent about the budget and that he wants to invest. So, he

\footnotetext{
2 Two main types of EPC are widely adopted: the 'shared savings' and 'guaranteed savings' contracting models, which mainly differ according to the source of project financing. In the 'shared savings' model, the ESCO arranges the finance for the energy retrofit measures. Subsequently, the ESCO shares part of the savings with the customer over a specified contractual period. In the 'guaranteed savings' model, the customer is responsible for financing the project, and the ESCO guarantees a certain level of saving.
} 
said, for example, 'I'm looking for the best technology, the maximum efficiency with the best cost, but I don't mind paying a lot. So, don't be concerned about the budget, but be concerned about bringing me the best! I want really to be a role model for all the hotels in Sharjah!', you know, so that value really brings that excitement for us and for the ESCO about really finding that best technology solution. (Engineer, UCO)

As this quote indicates, the transparent communication structures across the triad supported value co-creation by better understanding customer priorities. In addition, ESCOs benefit from transparency in budgets because this enables them to recommend technologies that best fit their unique situation. The building of transparent communication avenues for elucidating the value proposition is an essential mediating activity performed by the UCO to enable value co-creation in the triad.

\section{Knowledge-enabling roles and activities}

Knowing, within service interactions, involves the mutual learning and knowledge renewal required to improve the value delivered to the customer (Ballantyne \& Varey, 2006). Table 4 lists the observed UCO intermediary knowledge-enabling roles and activities, notably knowledge repository and co-educator.

Table 4 Utility company (UCO) intermediary knowledge-enabling roles and activities

\begin{tabular}{ll}
\hline $\begin{array}{l}\text { UCO intermediary } \\
\text { knowledge-enabling roles }\end{array}$ & Activities observed \\
\hline Knowledge repository & $\begin{array}{c}\text { - Keeping a record of retrofit } \\
\text { service providers, suppliers and } \\
\text { technologies } \\
\text { - Documenting lessons learnt from } \\
\text { projects } \\
\text { - Disseminating information } \\
\text { through workshops, seminars } \\
\text { and conferences } \\
\text { - Educating the customer on } \\
\text { energy efficiency services and } \\
\text { technologies } \\
\text { - facilitating triadic knowledge } \\
\text { generation, application, renewal } \\
\text { and mutual learning }\end{array}$ \\
\hline
\end{tabular}

Utility company as the knowledge repository

In our case setting, the UCO has considerable 'expert' power (Goodman \& Dion, 2001; Hingley and Lindgreen, 2015) in the value co-creation process as a knowledge 'repository'. The UCO amasses considerable knowledge of retrofitting technologies and strategies from its interactions with many ESCOs and a wide range of customers across the programme. The UCO also captures lessons learnt from projects in terms of feasibility studies and measurement and verification data, quality assurance procedures, project success and potential future improvements, thus playing a pivotal role in knowledge generation, application and renewal across the triad. Representatives of the UCO often organise workshops and seminars and attend conferences to disseminate information and promote the programme to a broader audience. Notably, in our study, UCO representatives expressed their concern about the limitations of the knowledge they possess compared with ESCOs. Given the nature of their business, ESCOs are seen to be more knowledgeable than UCO representatives. One approach adopted by the UCO to enable them to build in-depth knowledge about the process and the technology and thus to better advise their potential customers is to retrofit their main headquarters building. This approach was described as 'leading by example' and was viewed as a testing ground for several technologies that they espouse to promote in the market.

\section{Utility company as co-educator}

The role of the UCO as a 'co-educator' was fostered by their representatives. It was clear to the team that convincing customers to engage with the programme would require education. Knowledge sharing was therefore pursued to strengthen the value co-creation relationship through educating the customer, as explained by the UCO's project manager:

So, I always hope that the customer gives us a chance as a team of energy efficiency to show them the best in the market, to share that knowhow with them and to bring them the best... to share that knowledge, to create that value between us, and to strengthen that relationship. (Project Manager, UCO) 
Therefore, a 'co-educator' role is played by the UCO. The UCO aims to educate the customer about energy efficiency. The UCO's representatives in our study saw themselves as 'change agents', espousing to change the customer's environmental behaviour through knowledge sharing. The aspiration is to equip the customer with the knowledge required to transfer these energy efficiency practices to other buildings and to spread the knowledge among their community. A UCO team member explained these aims as follows:

[...] and try to change the behaviour of the customer to make sure that they understand the benefits of that project. And we want, after we leave, we want the customer to take that behaviour and that efficiency into other buildings, to share that knowledge, to talk to others in the society, not only for one building. No, we want this to sustain as a behaviour. (Engineer, UCO)

On the ESCO side, as mentioned earlier, the UCO assists the ESCO in refining their proposal documents to align more closely with the customer requirement and also helps to ensure that the ESCO can formulate a value proposition that is satisfactory to the customer. These interactions facilitate knowledge generation, application and renewal and further support mutual learning in the triad. In what has been termed by some interviewees as a 'win-win-win situation', or what one could refer to as 'triadic satisfaction', the ESCO's offer (i.e. the value proposition) worked to facilitate the end-customer's satisfaction with the retrofit service offering and also aided in strengthening the relationship between the UCO and the ESCO. Referring to a particular hotel retrofit project, the UCO's Chief Efficienology Officer commented as follows:

So, they created that offer that will satisfy SEWA, satisfy the customer and also satisfy them. So, they are going to win, the customer will win the best offer, they will improve their building, and, again, we will win the satisfaction of both parties and the customer. (Chief Efficienology Officer, UCO)

Hence, these are mutually beneficial relationships among all the parties involved in developing a supporting structure that sustains further value-creating activities. This process could be referred to as the 'reciprocity of value propositions' (Ballantyne \& Varey, 2006). Thus, in a well-functioning triad, value is evaluated by the three parties involved, and their perception of value is mutually linked in reciprocal value propositions. It could be argued that these positive social change processes are proactively initiated and driven by the UCO, yielding beneficial outcomes in the form of positive environmental impacts.

\section{Discussion}

The purpose of this study was to seek a deeper understanding of how a UCO facilitates value cocreation in building energy service settings based on an in-depth, exploratory case study of an extensive retrofit programme in the Emirate of Sharjah, UAE. Specifically, the findings underline three distinct enabling roles and activities that a UCO intermediary can perform to facilitate value co-creation in the triadic setting of energy service, as discussed below. Figure 3 illustrates the UCO intermediation model that emerged from the study's findings.

The first set of activities underpin the relationshipenabling role played by the UCO. Notably, the UCO orchestrates the value network on the demand side by distinguishing potential customers; acting as the first entity to meet with the customer and explain to the customer the need to reduce their energy consumption; understanding and articulating the customer requirements and the drivers behind their motivation to reduce their energy consumption; and convincing the customer of the value of the retrofit. On the supply side, the UCO qualifies the ESCOs; selects and recommends the ESCOs that best fit the customer needs and requirements; and proposes specific suppliers and technology providers to the ESCO. Moreover, the UCO intermediary acts as a co-developer of trust by building goodwill trust and competence trust across the triad and brokering trust across the ESCO-customer interface. The need for trust is most important when the customer lacks adequate technical knowledge about the service as well as project management knowledge, and hence they depend on the UCO to guide them and act as their ally. Convincing the customer to commit to signing the EPC contract was considered a lengthy process by the ESCO representatives due to customers' general lack of knowledge regarding retrofitting, lack of understanding of the 


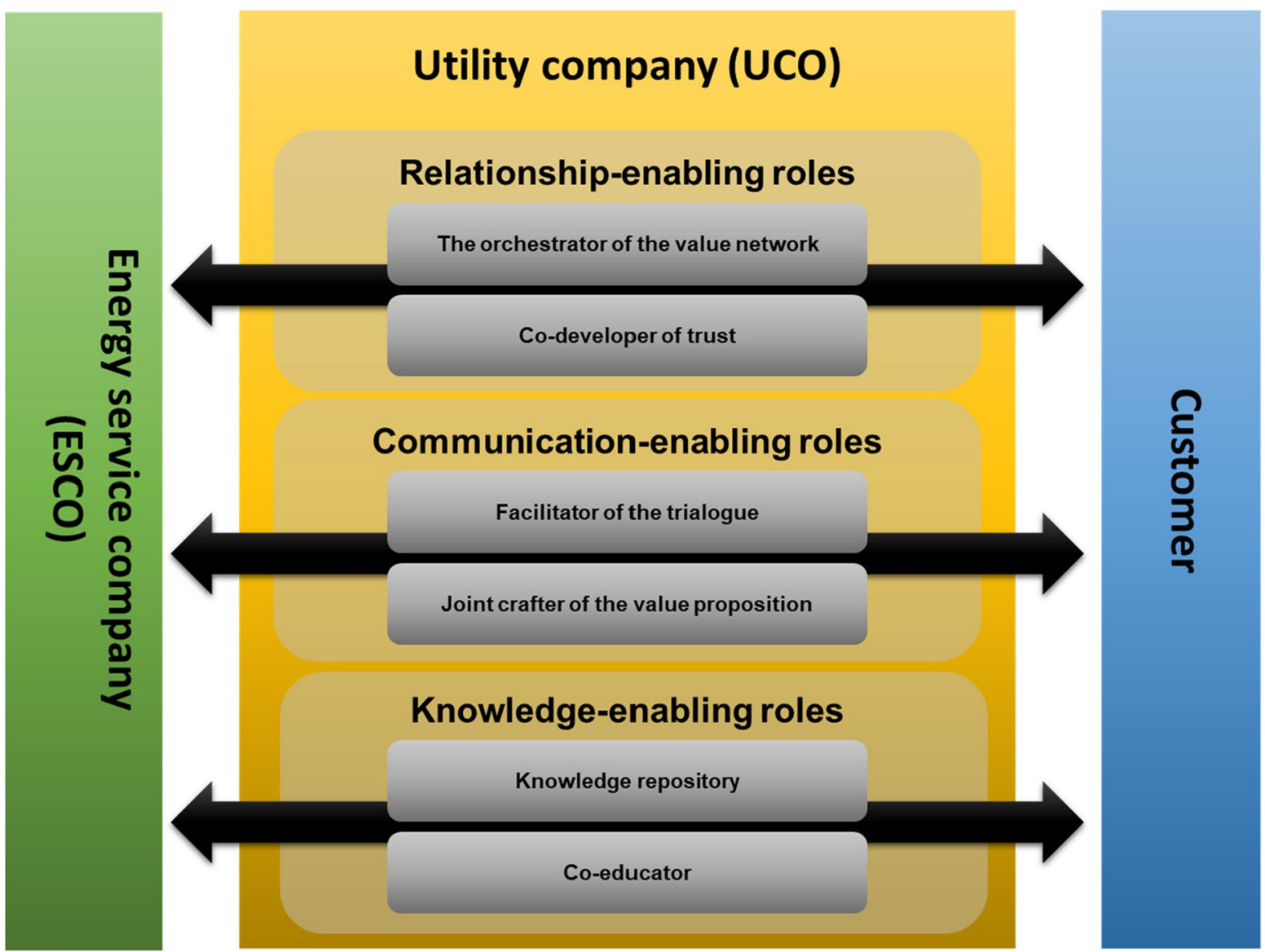

Fig. 3 Emergent utility company intermediation model

various ESC contract types offered and scepticism of the ESCO's capabilities. Hence, the role of the UCO was pivotal in convincing the customer to commit. The findings indicate that trust may be crucial in the highly uncertain context of building a retrofit market. Compared with the existing literature, the UCO intermediary is more proactive in contrast to the client-led approach in the case of the UK Carbon and Energy Fund (Nolden et al., 2016).

In addition, the ESCO procurement process in our case study is distinctly different from competitive procurement approaches identified in the literature, such as the multi-contractor competitors and tendering processes organised by intermediaries in the UK's Carbon and Energy Fund (CEF) (Nolden et al., 2016), European competitive dialogue procurement procedures (Bleyl et al., 2013) and the multidimensional auctions involved in Japanese ESCO projects
(Iimi, 2013). In the case setting, a direct recommendation is made by the UCO, with one ESCO recommended directly to the customer with no competition. This approach is not unusual in private-sector procurement, as a variety of purchasing modes are used in the private sector (Arlbjørn \& Freytag, 2012; Tadelis, 2012). However, the competitive bidding approach may offer an equal opportunity for registered ESCOs to bid for projects and may secure the best value for money for the customer (Bleyl et al., 2013; Nolden et al., 2016). Hence, the cost implications of this lack of competition cannot be ignored and signals the relative immaturity of this fledgeling market.

The second set of activities are associated with communication-enabling roles. The UCO intermediary facilitates the trialogue (i.e. three-way reciprocal communication) by guiding the customer 
through the retrofit journey and bridging the communication gap between the ESCO and the customer. The UCO intermediary also functions as a joint crafter of the value proposition by reviewing offers prepared by the ESCOs, negotiating with the ESCOs to secure the best price for the customer and checking and approving the work of the ESCOs. These activities are typical of other intermediary roles documented in the literature (e.g. Nolden et al., 2016). An observed difference, however, is the UCO's attempts to reduce transaction costs by offering its facilitation services free of charge throughout the project life-cycle. This is distinct from noted intermediation costs in other settings, such as the UK CEF (Nolden et al., 2016), in which the intermediary recoups its cost by taking a portion of the guaranteed savings in the contract from the client and/or contractor. This strategy was intended to develop a trusting relationship between the UCO and the customer and ultimately to convince the customer to commit to the project. In addition, the promotion of transparent communication among triadic actors supports the development of value propositions that is the best fit for the customer.

The third set of activities underline the UCO's knowledge-enabling role. The UCO intermediary acts as a knowledge repository by keeping a record of retrofit service providers, suppliers and technologies and by documenting lessons learnt from projects. The UCO intermediary also assumes a co-educator's role by informing the customer about energy efficiency. None of the end-customers who contributed to this study was an expert in retrofit services, and most had limited knowledge about the retrofit market. Hence, during the process, the UCO takes an active role in ensuring that the customer is suitably informed about the ESCO market and has clear expectations of the service offering. Without such support, the customers might be reluctant to engage with the service. The UCO also facilitates triadic knowledge generation, application and mutual learning. By influencing the triad via reward and expert power, the UCO pursued beneficial relationships among all the parties, with the perception of value mutually linked in reciprocal value propositions. Hence, the observed impetus towards energy efficiency and retrofitting is ultimately a triadic dynamic resulting from the cumulative learning of the individual decision-makers within the UCO, ESCO and the customer. In this way, the triadic actors leverage the ESCO market-based mechanism to drive positive social change (Stephan et al., 2016) and co-create value for greater energy efficiency.

\section{Conclusion and implications}

The SEWA case study in the UAE underlines the vital role that a UCO can play as an intermediary to foster the development of ESCO markets. Despite the study's exploratory nature, its findings make several noteworthy contributions to the current literature. First, while triads have been studied in service settings before (e.g. Hartmann \& Herb, 2015; Li \& Choi, 2009; Nätti et al., 2014), this study is the first to examine triadic relationships in the unique setting of energy service. Specifically, the study illustrates 1) the main value co-creation activities of the triadic actors and how they influence each other; 2) how the triadic approach can facilitate value co-creation through co-production of reciprocal value propositions, effective trialogue, co-production of knowledge and mutual learning; 3) how the triadic approach encourages the development of trust and the promotion of transparency between the triadic actors; and 4) the role of power dynamics in orchestrating value co-creation in the triad. Secondly, the study builds a conceptual understanding of the role of the UCO intermediary in facilitating value co-creation in the triad through assuming relationship-, communication- and knowledge-enabling roles. The emergent intermediation model extends Ballantyne and Varey's (2006) exchange enablers model to a triadic conceptualisation (Fig. 2) and provides a coherent theory of UCO-led intermediation that can be tested by future studies. Thirdly, the study documents the experiences of private-sector customers in the demand side of ESCO markets, addressing the paucity of research on the strategies for effectively motivating this important market segment, especially in the Middle East.

The study has several managerial and policy implications. First, the UCO intermediation model (Fig. 2) underlines how utility companies can facilitate the co-creation of value at the ESCO-customer interface. The model could be institutionalised on a larger scale to support the procurement of energy service projects on a national level. Policymakers should encourage an active role for UCOs as intermediaries in the ESCO markets for energy services. The utility sector 
could be motivated to assume this role through direct funding or subsidies to ensure the long-term sustainability of intermediation services. Secondly, the findings also highlight that a functioning triad should not be contingent on the UCO's efforts alone. The customers need to assume their role as a key actor in the triadic value co-creation relationship. Potential customer organisations need to be more knowledgeable about the ESCO contracting model and commit to greater environmental sustainability. Policymakers should invest in raising environmental awareness among customers and promoting energy service, emphasising pro-environmental behaviour change beyond an economic logic. Thirdly, the study highlights the pivotal role played by talented and highly motivated UCO employees. Hence, the senior managers at UCOs should not ignore their employees' skillsets in interfacing with ESCOs and the customer throughout the project development stages. The UCO employees tasked with these enabling activities should be selected based on advanced interpersonal, communication and project management skills. Complementary to this skillset is knowledge of the procurement of EPC contracts, structuring of finance and life-cycle cost evaluation for assessing the ESCO offers. Knowledge of measurement and verification procedures and quality management are also crucial for evaluating key performance indicators, notably the savings achieved during the EPC contract.

Our study has several limitations, some of which could be considered as opportunities for future research. First, our study is exploratory and focuses on a unique UCO in a unique Arab setting. Hence, this may limit the findings' generalisability, as the growth of ESCO markets varies worldwide, notably among developed and developing countries. Future research could expand the present study by examining other utility-sector intermediation models in the other UAE Emirates (e.g. DEWA's Super ESCO model) and internationally to analyse potential similarities and differences. The emergent intermediation model provides a coherent theory of UCO-led intermediation that can be tested by future studies. The paper also prompts a number of questions: for instance, around how trust and transparency interlink for value co-creation in energy service, what the relationship is between intermediary power, influence and value co-creation and what the implications are of national culture in intermediary relationships in ESCO markets. The fine-tuning of these relationship dynamics can be fruitful for further research.

In conclusion, the findings suggest that UCO intermediation could form a promising and workable approach to encouraging ESCO market development in the private sector and ultimately contributing to national sustainable development policies.

\section{Appendix}

Table 5 Interview protocol

\begin{tabular}{|c|c|}
\hline Concept & $\begin{array}{l}\text { Corresponding Interview } \\
\text { Question(s) }\end{array}$ \\
\hline Company background & $\begin{array}{l}\text { Main business offerings, number } \\
\text { of employees, years of operation, } \\
\text { organisational structure, mission } \\
\text { and key strategic objectives }\end{array}$ \\
\hline Project role & $\begin{array}{l}\text { - What is your company's role in the } \\
\text { retrofit project? } \\
\text { - When did your company become } \\
\text { involved? } \\
\text { - How did your company become } \\
\text { involved? }\end{array}$ \\
\hline $\begin{array}{l}\text { Value co-creation rela- } \\
\text { tionships }\end{array}$ & $\begin{array}{l}\text { - How long have you known this } \\
\text { UCO/ESCO/CUS? } \\
\text { - What is the nature of your rela- } \\
\text { tionship with the UCO/ESCO/ } \\
\text { customer on this project? } \\
\text { - Please describe how you com- } \\
\text { municated with the UCO/ESCO/ } \\
\text { customer during this project } \\
\text { - Are you satisfied with your } \\
\text { relationship with the UCO/ESCO/ } \\
\text { customer on this project? Why/ } \\
\text { why not? }\end{array}$ \\
\hline $\begin{array}{l}\text { Dynamics of the triadic } \\
\text { relationship }\end{array}$ & $\begin{array}{l}\text { - In your view, how did the triadic } \\
\text { relationships of the UCO/ESCO/ } \\
\text { customer on this project influence } \\
\text { each other? } \\
\text { - In your view, what are the advan- } \\
\text { tages of the triadic relational } \\
\text { model in delivering retrofit pro- } \\
\text { jects? What are the disadvantages? }\end{array}$ \\
\hline
\end{tabular}

\section{Declarations}

Conflict of interest The authors declare no competing interests. 


\section{References}

Aarikka-Stenroos, L., \& Jaakkola, E. (2012). Value co-creation in knowledge-intensive business services: A dyadic perspective on the joint problem-solving process. Industrial Marketing Management, 41(1), 15-26.

Alam, M., Zou, P. X., Stewart, R. A., Bertone, E., Sahin, O., Buntine, C., \& Marshall, C. (2019). Government championed strategies to overcome the barriers to public building energy efficiency retrofit projects. Sustainable Cities and Society, 44, 56-69.

Arlbjørn, J. S., \& Freytag, P. V. (2012). Public procurement vs private purchasing: is there any foundation for comparing and learning across the sectors? International Journal of Public Sector Management., 25(3), 203-220.

Barnes, B. R., Naudé, P., \& Michell, P. (2007). Perceptual gaps and similarities in buyer-seller dyadic relationships. Industrial Marketing Management, 36(5), 662-675.

Ballantyne, D., \& Varey, R. J. (2006). Creating value-in-use through marketing interaction: The exchange logic of relating, communicating and knowing. Marketing Theory, 6(3), 335-348.

Barbose, G. L., Goldman, C. A., Hoffman, I. M., \& Billingsley, M. (2013). The future of utility customer-funded energy efficiency programs in the USA: Projected spending and savings to 2025. Energy Efficiency, 6(3), 475-493.

Barrett, M., Davidson, E., Prabhu, J., \& Vargo, S. L. (2015). Service innovation in the digital age: Key contributions and future directions. MIS Quarterly, 39(1), 135-154.

Bertoldi, P., Rezessy, S., \& Vine, E. (2006). Energy service companies in European countries: Current status and a strategy to foster their development. Energy Policy, 34, 1818-1832.

Bertoldi, P., \& Boza-Kiss, B. (2017). Analysis of barriers and drivers for the development of the ESCO markets in Europe. Energy Policy, 107, 345-355.

Bertoldi, P., Economidou, M., Palermo, V., Boza-Kiss, B., Todeschi, V. (2021). How to finance energy renovation of residential buildings: Review of current and emerging financing instruments in the E.U. Wiley Interdisciplinary Reviews: Energy and Environment, 10(1), e384.

Beverland, M., \& Lindgreen, A. (2010). What makes a good case study? A positivist review of qualitative case research published in Industrial Marketing Management, 1971-2006. Industrial Marketing Management, 39(1), 56-63.

Bleyl, J.W., Adilipour, N., Bareit, M., Kempen, G., Cho, S.-H., Vanstraelen, L., (2013). ESCo market development: A role for Facilitators to play", ECEEE summer study proceedings 2013, (Belambra Les Criques, France).

Bryman, A., \& Burgess, R. (1994). Analysing Qualitative Data. Routledge.

Bull, J., Gupta, A., Mumovic, D., \& Kimpian, J. (2014). Life cycle cost and carbon footprint of energy-efficient refurbishments to 20th century UK school buildings. International Journal of Sustainable Built Environment, 3(1), 1-17.

Chowdhury, I. N., Gruber, T., \& Zolkiewski, J. (2016). Every cloud has a silver lining-Exploring the dark side of value co-creation in B2B service networks. Industrial Marketing Management, 55, 97-109.

Clean Energy Business Council (2019). ESCO Market in MENA: Challenges vs Opportunities, [Online]. Available from: https://cebcmena.com/wp-content/uploads/ delightful-downloads/2019/09/CEBC-White-PaperESCO-Market-in-MENA_Challenges-vs-Opportunit ies-September-2019.pdf.

Construction Week (2018). 'Efficienology' chief on reinventing Sharjah's energy landscape [Online] [Accessed 17 February 2021] available online: https://www.const ructionweekonline.com/article-49122-efficienologychief-on-reinventing-sharjahs-energy-landscape.

Cova, B., \& Salle, R. (2008). Marketing solutions in accordance with the S-D logic: Co-creating value with customer network actors. Industrial Marketing Management, $37,270-277$.

Das, T. K., \& Teng, B. S. (2001). Trust, control, and risk in strategic alliances: An integrated framework. Organisation Studies, 22(2), 251-283.

Dorsch, M. J., Swanson, S. R., \& Kelley, S. W. (1998). The role of relationship quality in the stratification of vendors as perceived by customers. Journal of the Academy of Marketing Science, 26(2), 128-142.

De Wilde, M., \& Spaargaren, G. (2019). Designing trust: How strategic intermediaries choreograph homeowners' lowcarbon retrofit experience. Building Research \& Information, 47(4), 362-374.

Doney, P. M., \& Cannon, J. P. (1997). An examination of the nature of trust in buyer-seller relationships. Journal of Marketing, 61(2), 35-51.

Dubey, K., Krarti, M. (2017). Economic and Environmental Benefits of Improving UAE Building Stock Energy Efficiency, King Abdulla Petroleum Studies and Research Centre, [Online] [Accessed 23 July 2020] available online: https://www.kapsarc.org/research/publications/ economic-and-environmental-benefits-of-improving-uaebuilding-stock-energy-efficiency/.

Eggert, A., \& Helm, S. (2003). Exploring the impact of relationship transparency on business relationships: A crosssectional study among purchasing managers in Germany. Industrial Marketing Management, 32(2), 101-108.

Eisenhardt, K. M. (1989). Building theories from case study research. Academy of Management Review, 14(4), 532-550.

Eisenhardt, K. M., \& Graebner, M. (2007). Theory Building from Cases: Opportunities and Challenges. Academy of Management Journal, 50(1), 25-32.

Eto, J., Vine, E., Shown, L., Sonnenblick, R., Payne, C. (1996). The total cost and measured performance of utility-sponsored energy efficiency programs. The Energy Journal, 17(1).

Fang, W. S., Miller, S. M., \& Yeh, C.-C. (2012). The effect of ESCOs on energy use. Energy Policy, 51, 558-568.

Flyvbjerg, B. (2006). Five Misunderstandings About Case Study Research. Qualitative Inquiry, 12(2), 219-245.

Ford, D., \& Håkansson, H. (2013). Competition in business networks. Industrial Marketing Management, 42, 1017-1024.

French, J., \& Raven, B. (1959). The bases of social power'. In D. Cartwright \& A. Zander (Eds.), Group Dynamics (pp. 150-167). Harper and Row. 
Friedrich, K., Eldridge, M., York, D., Witte, P., Kushler, M. (2009). Saving energy cost-effectively: a national review of the cost of energy saved through utility-sector energy efficiency programs. American Council for an Energy-Efficient Economy. September.

Frow, P., McColl-Kennedy, J. R., Hilton, T., Davidson, A., Payne, A., \& Brozovic, D. (2014). Value propositions: A service ecosystems perspective. Marketing Theory, 14(3), 327-351.

Garbuzova-Schlifter, M., \& Madlener, R. (2013). Prospects and barriers for Russia's emerging ESCO market. International Journal of Energy Sector Management, 7(1), 113-150.

Glaser, B. G., \& Strauss, A. L. (1967). The discovery of grounded theory: Strategies for qualitative research. Aldine.

Goodman, L. E., \& Dion, P. A. (2001). The determinants of commitment in the distributor-manufacturer relationship. Industrial Marketing Management, 30(3), 287-300.

Grönroos, C. (2008). Service logic revisited: Who creates value? And who co-creates? European Business Review, 20(4), 298-314.

Hartmann, E., \& Herb, S. (2015). Interconnectedness of actor bonds in service triads-a social capital perspective. Industrial Marketing Management, 44, 154-165.

Hannon, M. J., Foxon, T. J., \& Gale, W. F. (2015). 'Demand pull'government policies to support Product-Service System activity: The case of Energy Service Companies (ESCos) in the UK. Journal of Cleaner Production, 108, 900-915.

Havila, V., Johanson, J., \& Thilenius, P. (2004). International business-relationship triads. International Marketing Review, 21(2), 172-186.

Hewett, K., Money, R. B., \& Sharma, S. (2002). An exploration of the moderating role of buyer corporate culture in industrial buyer-seller relationships. Journal of the Academy of Marketing Science, 30(3), 229-239.

Hibbard, J. D., Kumar, N., \& Stern, L. W. (2001). Examining the impact of destructive acts in marketing channel relationships. Journal of Marketing Research, 38(1), 45-61.

Hingley, M., Angell, R., \& Lindgreen, A. (2015). The current situation and future conceptualisation of power in industrial markets. Industrial Marketing Management, 48, 226-230

Hogan, J. E. (2001). Expected relationship value: A construct, a methodology for measurement, and a modeling technique. Industrial Marketing Management, 30(4), 339-351.

Holbrook, M. B. (1994). The nature of customer value. In R. T. Rust \& R. L. Oliver (Eds.), Service Quality: New Directions in Theory and Practice (pp. 21-71). Sage Publications.

Hultman, J., \& Axelsson, B. (2007). Towards a typology of transparency for marketing management research. Industrial Marketing Management, 36(5), 627-635.

IEA (2019a). Energy Efficiency 2019, [Online] [Accessed 21 February 2021] Available from: https://www.iea.org/ reports/energy-efficiency-2019.

IEA (2019b). The Critical Role of Buildings - Perspectives for the Clean Energy Transition. International Energy Agency.
IEA (2020). Energy Efficiency 2020, [Online] [Accessed 21 February 2021] Available from: https://www.iea.org/ reports/energy-efficiency-2020.

Iimi, A. (2013). Multidimensional auctions for public energy efficiency projects: Evidence from the Japanese ESCO market. The World Bank.

International Energy Agency. (2019). Tracking Buildings. International Energy Agency.

Jafari, A., \& Valentin, V. (2017). An optimisation framework for building energy retrofits decision-making. Building and Environment, 115, 118-129.

Jiang, X., Li, M., Gao, S., Bao, Y., \& Jiang, F. (2013). Managing knowledge leakage in strategic alliances: The effects of trust and formal contracts. Industrial Marketing Management, 42(6), 983-991.

Kneifel, J. (2010). Life-cycle carbon and cost analysis of energy efficiency measures in new commercial buildings. Energy and Buildings, 42(3), 333-340.

Krarti, M. (2015). Evaluation of large scale building retrofit program in Kuwait. Renewable and Sustainable Energy Reviews, 50, 1069-1080.

Lambert, D. M., \& Enz, M. G. (2012). Managing and measuring value co-creation in business-to-business relationships. Journal of Marketing Management, 28(13-14), 1588-1625.

Larsen, P. H., Goldman, C. A., \& Satchwell, A. (2012). Evolution of the US energy service company industry: Market size and project performance from 1990-2008. Energy Policy, 50, 802-820.

Laud, G., Bove, L., Ranaweera, C., Leo, W. W. C., Sweeney, J., \& Smith, S. (2019). Value co-destruction: A typology of resource misintegration manifestations. Journal of Services Marketing., 33(7), 866-889.

Leech, N. L., Onwuegbuzie, A. J. (2011). Beyond constant comparison qualitative data analysis: Using NVivo. School Psychology Quarterly, 26(1), 70.

Leek, S., \& Mason, K. (2009). Network pictures: Building an holistic representation of a dyadic business-to-business relationship. Industrial Marketing Management, 38(6), 599-607.

Lewis, J. D., \& Weigert, A. (1985). Trust as a social reality. Social Forces, 63(4), 967-985.

Li, M., \& Choi, T. Y. (2009). Triads in services outsourcing: Bridge, bridge decay and bridge transfer. Journal of Supply Chain Management, 45(3), 27-39.

Limaye, D. R., \& Limaye, E. S. (2011). Scaling up energy efficiency: The case for a Super ESCO. Energy Efficiency, 4, 133-144.

Liu, Y., Liu, T., Ye, S., \& Liu, Y. (2018). Cost-benefit analysis for Energy Efficiency Retrofit of existing buildings: A case study in China. Journal of Cleaner Production, 177, 493-506.

Ma, Z., Cooper, P., Daly, D., \& Ledo, L. (2012). Existing building retrofits: Methodology and state-of-the-art. Energy and Buildings, 55, 889-902.

Marino, A., Bertoldi, P., \& Rezessy, S. (2010). Energy service companies market in Europe-status report 2010. Publications Office of the European Union.

Moorman, C., Deshpande, R., \& Zaltman, R. (1993). Factors affecting trust in market research relationships. Journal of Marketing, 57(1), 81-101. 
Moran, P., O'Connell, J., \& Goggins, J. (2020). Sustainable energy efficiency retrofits as residenial buildings move towards nearly zero energy building (NZEB) standards. Energy and Buildings, 211, 109816.

Morgan, R. M., \& Hunt, S. D. (1994). The commitment-trust theory of relationship marketing. Journal of Marketing, 58(3), 20-38.

Murto, P., Jalas, M., Juntunen, J., \& Hyysalo, S. (2019). The difficult process of adopting a comprehensive energy retrofit in housing companies: Barriers posed by nascent markets and complicated calculability. Energy Policy, 132, 955-964.

Nätti, S., Pekkarinen, S., Hartikka, A., \& Holappa, T. (2014). The intermediator role in value co-creation within a triadic business service relationship. Industrial Marketing Management, 43(6), 977-984.

Neumann, W. L. (2000). Social Science Research Methods: Qualitative and Quantitative Approaches. Allyn and Bacon.

Nolden, C., Sorrell, S., \& Polzin, F. (2016). Catalysing the Energy Service Market: The Role of Intermediaries. Energy Policy, 98, 420-430.

Okay, E. (2020). More Obstacles to the Growth of ESCOs in Turkey: Stumble In the Midst of a Financial Distress. In Handbook of Research on Creating Sustainable Value in the Global Economy. IGI Global. 125-145.

Owen, A., Mitchell, G., \& Gouldson, A. (2014). Unseen influence-The role of low carbon retrofit advisers and installers in the adoption and use of domestic energy technology. Energy Policy, 73, 169-179.

Nooteboom, B. (1996). Trust, opportunism and governance: A process and control model. Organisation Studies, 17(6), 985-1010.

Pätäri, S., Annala, S., Jantunen, A., Viljainen, S., \& Sinkkonen, A. (2016). Enabling and hindering factors of diffusion of energy service companies in Finland-results of a Delphi study. Energy Efficiency, 9(6), 1447-1460.

Perkins, W. S. (1993). Measuring customer satisfaction. Industrial Marketing Management, 22(3), 247-254.

Pombo, O., Rivela, B., \& Neila, J. (2019). Life cycle thinking toward sustainable development policy-making: The case of energy retrofits. Journal of Cleaner Production, 206, 267-281.

Recalde, M. Y. (2021). Which aspects may prevent the development of energy service companies? The impact of barriers and country-specific conditions in different regions. In Energy Services Fundamentals and Financing. Academic Press. 293-315.

Ritter, T. (2000). The framework for analysing interconnectedness of relationships. Industrial Marketing Management, 29, 317-326.

Sampson, S. E., \& Spring, M. (2012). Customer roles in service supply chains and opportunities for innovation. Journal of Supply Chain Management, 48(4), 30-50.

Slack, N., Brandon-Jones, A. (2019), Operations Management, $9^{\text {th }}$ Edition.

Sorrell, S. (2007). The economics of energy service contracts. Energy Policy, 35(1), 507-521.

Stephan, U., Patterson, M., Kelly, C., \& Mair, J. (2016). Organisations driving positive social change: A review and an integrative framework of change processes. Journal of Management, 42(5), 1250-1281.
Svensson, G. (2002). A triadic network approach to service quality. Journal of Services Marketing, 16(2), 158-179.

Svensson, G. (2004). Triadic trust in business networks: A conceptual model and empirical illustration. European Business Review, 16(2), 165-190.

Tadelis, S. (2012). Public procurement design: Lessons from the private sector. International Journal of Industrial Organization, 30(3), 297-302.

Tanskanen, K., \& Aminoff, A. (2015). Buyer and supplier attractiveness in a strategic relationship-A dyadic multiple-case study. Industrial Marketing Management, 50, 128-141.\#

Taylor, R. P., Govindarajalu, C., Levin, J., Meyer, A. S., Ward, W. A. (2008). Financing energy efficiency: Lessons from Brazil, China, India, and Beyond, Energy Sector Management Assistance Program (ESMAP). World Bank. https://openknowledge.worldbank.org/ handle/10986/6349 License: CC BY 3.0 IGO.

Ulaga, W., \& Eggert, A. (2006). Relationship value and relationship quality: Broadening the nomological network of business-to-business relationships. European Journal of Marketing, 40(3-4), 311-327.

United Nations (2017), Global status report: Towards a zeroemission, efficient and resilient buildings and commercial sector, [online] [Accessed 21 July 2020] Available from: https://www.worldgbc.org/sites/default/files/ UNEP\%20188_GABC_en\%20\%28web\%29.pdf.

Vargo, S. L., \& Lusch, R. F. (2008). Service-dominant logic; further evolution. Journal of the Academy of Marketing, 36(1), 1-10.

Vargo, S. L., \& Lusch, R. F. (2012). The nature and understanding of value: A service-dominant logic perspective. Review of Marketing Research, 9(1), 1-12.

Vargo, S. L., Wieland, H., \& Akaka, M. A. (2015). Innovation through institutionalisation: A service ecosystems perspective. Industrial Marketing Management, 44, 63-72.

Vedel, M. (2010) Value Creation in Triadic Business Relationships: Interaction, Interconnection and Position, PhD Series, No. 28.2010, ISBN 9788759384411, Copenhagen Business School (CBS), http://hdl.handle. net/10398/8165.

Vine, E. (2005). An international survey of the energy service company (ESCO) industry. Energy Policy, 33, 691-704.

Wieland, H., Polese, F., Vargo, S. L., \& Lusch, R. F. (2012). Toward a service (eco) systems perspective on value creation. International Journal of Service Science, Management, Engineering, and Technology (IJSSMET), 3(3), 12-25.

Wilson, D. T. (1995). An integrated model of buyer-seller relationships. Journal of the Academy of Marketing Science, 23(4), 335-345.

Yeh, L. J., Hu, J. Y., \& Chen, Z. (2021). The Internationalization-Performance Relationship of Small-and-Mediumsized Enterprises: The Case of Taiwan ESCO Industry. Journal of Applied Finance \& Banking, 11(1), 41-60.

Yin, R. (2003). Case Study Research: Design and Methods (3rd ed.). Sage Publishing.

Yushchenko, A., \& Patel, M. K. (2017). Cost-effectiveness of energy efficiency programs: How to better understand 
and improve from multiple stakeholder perspectives? Energy Policy, 108, 538-550.

Zhou, Y., Evans, M., Yu, S., Sun, X., Wang, J. (2020). Linkages between policy and business innovation in the development of China's energy performance contracting market. Energy Policy, 140, 111208.

Zhu, X. (2020). China's Remarkable Success in Developing ESCOs: Current Status, Policy Drivers, and Prospects. In Incorporating Energy Service Companies in Nationally
Determined Contributions-The potential of ESCOs for meeting the climate goals in the Paris Agreement. 119-133.

Zikmund, W. G. (2000). Business Research Methods. Dryden Press.

Publisher's note Springer Nature remains neutral with regard to jurisdictional claims in published maps and institutional affiliations. 